\title{
The Attitude of Muslim Scholars to New Approaches in Religious Studies
}

Muslim scholars in Islamic studies have often been characterized by western scholars of religion as a "conservative group" (Martin 1985). This charge is brought against them because of their reluctance to adopt the theories and methodologies of the science of religion in their approach to the study of Islam and Muslim societies. I would like to outline three major factors responsible for the "conservatism" of contemporary Muslim scholars in an attempt to contribute to an understanding of their position. The first is concerned with objectives, the second with history, while the third deals with approaches.

Objectives: For Muslim scholars, the acquisition and imparting of knowledge has to be purposeful and meaningful. They do not subscribe to the philosophy of pursuing knowledge for its own sake. Any study of Islam or of Muslim society must of necessity be goal oriented. The essential distinction between the approaches of contemporary western scholars of Islam and those of Muslim scholars can be attributed to their respective goals. For western scholars, the purpose of Islamic studies is primarily to increase the understanding of Islam, its people, culture, society, and civilization. For Muslim scholars, the purpose is not only to produce graduates well-versed in various aspects of Muslim history, culture, and civilization, but also to equip them to tackle or solve contemporary problems facing Muslim societies (Sardar 1983). It must be expected, therefore, that Muslim scholars will remain reluctant to adopt new approaches as long as they are convinced that they serve no practical purpose.

The Historical Factor: This has to do primarily with the historical role of the orientalists. Muslim scholars acknowledge that the early generation of orientalists rendered useful services to Arabic and Islamic scholarship, especially through their critical edition and publication of manuscript texts (Tibawi 1979; Jameelah 1971). However, the scholarly output of orientalism on the whole leaves much to be desired. In the precolonial era, it was characterized by abusive polemics and false representation (Said 1978; Jameelah 1971), which the subsequent European occupation of Muslim lands aggravated even further. The reason for this misrepresentation was that those who wrote on Islam were scholars of Biblical, theological, or linguistic studies and not of Islam. It was not uncommon for their only contact with Islam to be the result of military or missionary activity or residence in a Muslim region. Most of their writings could be 
described as "speculative," their characteristic features being that Biblical tradition provided the norm for Islam and that western civilization provided the norm for Islamic civilization (Manzoor 1986).

This theologically reductionist approach, in which Islam was understood within a western Christian paradigm, lasted until the middle of the eighteenth century (Al Fārūqī 1989). In recent years, not only the authority but even the very institution of orientalism has been challenged by many prominent scholars of Islam, such as A. L. Tibawi, S. H. Alatas, A. Abdel Malek, Talal Asad, Abdallah Laroui, and Edward Said (Said 1985). However, while the orientalist approach has by and large been discredited, Muslim scholars remain suspicious about the intentions of contemporary western scholars of Islam. Naturally, this suspicion makes them reluctant to consider new approaches suggested by these scholars.

Approaches: Muslim scholars can identify with the religionist approach which developed in the nineteenth century. This approach accepts the existence of the "other" realm, concedes the possibility of interaction with spiritual beings, and describes humanity as religious by nature.

However, they have serious problems with the naturalistic approach that developed in the nineteenth century. This view holds that religious phenomena can be studied via nomothetic methods, because the subject matter of religion is the of same type as that of natural science. ${ }^{1}$ Muslim scholars reject this approach, for its focus is on empirical elements in religion, such as buildings, rituals, and texts, and cannot "do justice to the experience of transcendental realities" (Mostert 1980). Science also does not pay attention to personal awareness and intuition (Wiebe 1980).

Furthermore, the basic assumptions of science are that every event in nature is determined by prior natural events and that the character of this determinism can be discerned through scientific investigation (Glock and Stark 1966). Science accepts only those "truths" which are logically or empirically determinable. For Islam, intuition, personal awareness, and the transcendent reality are vital. ${ }^{2}$ Moreover, Islam teaches that human beings are responsible for their own actions ${ }^{3}$ and that the human personality does not consist only of "natural" or physical elements observable by the senses, but also of a "spiritual" element without which a proper understanding of religious phenomena is not possible.

\footnotetext{
'"Human society exhibits regularities consistent with those found in the rest of nature and ... these can be discovered by the same procedures as have been used to discover what are called the laws of nature" (Fortes 1953).

2"... and $\mathrm{He}$ is Omnipotent over His servants" (Qur'an 6:18), and "Such is God, your real Cherisher and Sustainer" (Qur'an 10:32).

${ }^{3 \prime}$ Then shall anyone who has done an atom's weight of good see it. And anyone who has done an atom's weight of evil shall see it" (Qur'an 99: 6-8).
} 
As a result of these assumptions, the approach of such disciplines as the positivist school of sociology and anthropology and the behaviorist school of psychology, which assume that human behavior is determined in the same way as other natural phenomena, will not receive the serious attention of Muslim scholars. The sociological and psychological subdisciplines of the science of religion are conditioned largely by the scientific assumptions of the social sciences.

Naturally, the positivist reductionist theories of religion which seek to explain the causes of the emergence of religion as a human institution are not acceptable to Muslim scholars. This includes the explanation of religion as an outcome of human desires, needs, and wants such as class interests, social solidarity, wish fulfillment, and the drive towards individuation and the maximation of well-being. The depictions of religion as a purely human reality, ${ }^{4}$ a social phenomenon (Pickering 1987; O'Dea 1983), a mechanism of emotional adjustment (Johnstone 1975), a cultural expression (Spiro 1966), a constitutive element of human consciousness, or as a result of some universal human response to the environment (Johnstone 1975) are equally unacceptable to Muslim scholars. Thus Freud's descriptions of religion as a neurotic or pathological condition (Sutherland 1957), as an illusion (O’Dea 1983), or as a psychological process projected into the outer world (Jones 1957), as well as Jung's depictions of religion as a normal expression of the human psyche (Jung 1962), as a system of psychic healing (Jung 1954), and of God as a function of the unconscious (Jung 1961), will be rejected by Muslim scholars.

Muslim scholars will not support a position that denies the existence of a spiritual force or being beyond this world and the possibility of human interaction with the "invisible realm" (Pickering 1984). While social scientists reject the intervention of God as a causal factor in human events, this factor is fundamental for Muslims (Glock and Stark 1966). They certainly cannot agree with Durkheim's depiction of God as a symbolic representation of society (Parsons 1968). For them, humanity's religious experience is a response to the divine reality and is concerned with the religious life of humanity and its relationship to the transcendent.

Other popular explanations of religion as an anachronism, a "survival" mechanism, or an atavistic relapse into a mode of thought that an "enlightened" humanity has outgrown will fail to attract the interest of even the most "liberal" Muslim scholars (James 1958). Likewise the paradigm provided by Marxism, with its doctrine of dialectical materialism that reduces all spiritual doctrines to crass economic factors and denies the tran-

${ }^{4}$ According to Durkheim, all that is religious is created by man (Pickering 1984). See also McGuire (1987). 
scendent in human history, will not receive the consideration of Muslim scholars. While Marx views religion as merely a product of the socioeconomic factors of a given society, ${ }^{5}$ Muslim scholars cannot conceive of Islam as linked with any identifiable socioeconomic context or variable.

Although the positivist approach was criticized by many scholars during the $1950 \mathrm{~s}$, the empiricism that replaced it contained many of its assumptions. During the 1960 s, the empiricist claim that all observable data could be described in pure observation-language independent of theoretical assumptions was challenged. Both the procedures for making observations as well as the language in which data are reported have been shown to be theory-laden (Barbour 1974). According to Parsons (1968), social science is grounded in culture. This being so, it is reasonable to assume that the explanations of the social scientists are to a greater or lesser degree "culture bound."

Having recognized the subjective nature of the social sciences, some contemporary Muslim scholars are now attempting to locate the social sciences within an Islamic paradigm (Al Fārūqī 1989). Their position is that the Islamic worldview should determine the perspectives the social science disciplines. Furthermore, the disciplines of history, sociology, anthropology, philosophy, and psychology have a serious limitation, i.e. they deal with only a partial model of religion. While some disciplines study only the behavior of groups, others study the behavior of individuals in a group. A comprehensive understanding of any religious tradition-including Islam - cannot be achieved without the study of both. Moreover, a single discipline, such as sociology, will study only the sociological aspects of a religion (i.e., the behavior of a religious community), thus yielding partial results. Muslim scholars favor multidisciplinary and interdisciplinary approaches to study and explain particular events and phenomena in order to produce a more synthesized view.

Recently the phenomenological approach has come to play a significant role in the development of the "scientific" study of religion. This approach, characterized by "epoche" and "empathy," presupposes that religion can be understood as an objective reality. But, it is questionable whether it is possible to study anything without a priori norms, preconceived notions, and preconvictions. Studies show that complete objectivity is not attainable (Weber 1949; Smith 1981; Barbour 1976). In fact, phenomenologists have been charged with an unconscious commitment to reductionist-type presuppositions (Cumpsty 1990). When they engage in the observation of regularities and classification of types, they operate

5" ... man makes religion; religion does not make man" (McLellan 1977). See also McGuire (1987). 
on the basis of theories that are value-laden. Furthermore, even if we accept that the phenomenological approach is an ideal not to be attained but rather aspired for, Muslim scholars find it extremely difficult to conceive of Islam as merely a social phenomenon or entity, or as an objective and empirical category to be studied. Muslim scholars' adoption of the phenomenological approach is therefore likely to be conditional.

The study of religion has also been influenced by the doctrine of humanism. The history and phenomenology of religion are rooted in the humanistic approach to religion (Chidester 1985). The humanistic doctrine that has influenced the disciplines of history, psychology, sociology, economics, and politics exalts humanity over everything else in the universe, endowing it with ultimate value. Although human beings are the primary focus of the Qur'an, for Muslims God is the ultimate reality and the primary focus of attention. ${ }^{6}$ The humanistic approach, therefore, is seriously flawed as far as Muslim scholars are concerned.

From the above discussion, it should be clear that most Muslim scholars are unlikely to adopt a nonnormative approach to the study of Islam and Muslim societies. The adoption of a "non-ideological" approach poses serious theological problems for Muslim scholars. Is it admissible to be agnostic or atheistic merely for the sake of academic enquiry?

In conclusion, it can be assumed that Muslim scholars may a) readily concede that modern scientific disciplines have given us a more comprehensive and profound view of religion than in previous generations and b) be prepared to adopt new techniques and methods in their approach to the study of Islam and Muslim societies. However, they will do so only from a normative position.

\section{References}

Ali, A. Yusuf. The Glorious Qur'an: Translation \& Commentary. Plainfield, IN: American Trust Publications, 1977.

Barbour, I.G. Myths, Models and Paradigms. San Francisco: Harper \& Row, 1976.

Chidester, D. "Theory and Theology in the Study of Religion." Religion in Southern Africa 6, no. 2 (1985).

Cumpsty, J. S. "The Academic Study of Religion." Journal for the Study of Religion 3, no. 1 (1990).

Al Fārūqī, I. R. "Towards a Critical World Theology." In Toward Islamization of Disciplines. Herndon, VA: International Institute of Islamic Thought, 1989.

"That is because God is the (only) Reality" (Qur'an 31:30). 
Fortes, M. Social Anthropology at Cambridge since 1900. London: Cambridge University Press, 1953.

Glock, C. Y. and R. Stark. Religion and Society in Tension. Chicago: Rand McNally, 1966.

Jameelah, M. Islam and Orientalism. Lahore: Mohammad Yusuf Khan, 1971.

James, W. Varieties of Religious Experience. New York: The New American Library, 1958.

Johnstone, R. L. Religion and Society in Interaction. New Jersey: Prentice-Hall Inc., 1975.

Jones, E. Sigmund Freud: Life and Work. London: The Hogarth Press, 1957.

Jung, C. G. The Practice of Psychotherapy, translated by R. F. C. Hull. London: Routledge \& Kegan Paul, 1954.

----. Psychology and Religion. New Haven, CT: Yale University Press, 1962.

----. Psychological Types, translated by R. F. C. Hull. New York: Bollingen, 1961.

Manzoor, S. P. "Studying Islam Academically." Afkar Inquiry 3, no. 4 (1986).

Martin, R. C., ed. Approaches to Islam in Religious Studies. Tucson, AZ: The University of Arizona Press, 1985.

McGuire, M. B. Religion: The Social Context. California: Wadsworth Publishing Co., 1987.

McLellan, D., ed. Karl Marx: Selected Works. Oxford, UK: Oxford University Press, 1977.

Mostert, J. P. "The Contribution of the Greek Enlightenment to the Intellectual Quest for Religion." Religion in South Africa 1, no. 1 (1980).

O'Dea, T. F. and J. O. Aviad. The Sociology of Religion. 2d ed. New Jersey: Prentice-Hall, 1983.

Parsons, T. The Structure of Social Action. Toronto: Collier-Macmillan Ltd., 1968.

----. Sociological Theory and Modern Society. New York: The Free Press, 1967.

Pickering, W. S. F. Durkheim's Sociology of Religion. London: Routledge \& Kegan Paul, 1984.

Said, E. W. "Orientalism Reconsidered." Race and Class XXVII:2. London: Institute of Race Relations, 1985.

----. Orientalism. London: Routledge \& Kegan Paul, 1978.

Sardar, Z. "The Future of Islamic Studies." Islamic Culture, vol. 57 (1983).

Smith, W. C. Towards a World Theology. London: The Macmillan Press, 1981. 
Spiro, M. E. "Problems of Definition and Explanation." In Anthropological Approaches to the Study of Religion, edited by M. Banton. London: Tavistock Publications, 1966.

Sutherland, J. D., ed. Sigmund Freud: Collected Papers, translated by J. Riviere. London: The Hogarth Press, 1957.

Tibawi, A. L. "Second Critique of English Speaking Orientalists and Approach to Islam and the Arabs." The Islamic Quarterly (1979).

Weber, M. The Methodology of the Social Sciences, translated and edited by E. A. Shils and H. A. Finch. New York: The Free Press, 1949. Wiebe, D. "Is a Science of Religion Possible?" In History of Religions, edited by M. Pye and P. McKenzie, Leister Studies in Religion II. England: Blackfriars, 1980.

Suleman Dangor

Dept. of Islamic Studies University of Durban-Westville Durban, South Africa

* Call for Papers *

\section{The Second Conference of Islamic Direction for the Social Services}

Cairo: 18-21 Safar 1414/ 7-10 August 1993

The International Institute of Islamic Thought is pleased to call upon all those involves in social service and related sciences to cooperate with the Arab League for Islamic Education in the Arab World by participating with their papers in the Second Conference for the Islamic Direction for the Social Services. Its theme will be "Fields of Social Service from an Islamic Viewpoint," and it will focus on the following topics:

1. Social growth and growth of the indigenous society;

2. Social considerations in various stages of life (the family, childhood, youth, and old age);

3. Social services in auxiliary fields (medical, scholastic, labor/financial, police, and armed forces social service);

4. Social services with special units in the field of deviance (delinquency, the gifted, innovation, prisoners); and

5. Social services in the fields of aid and call to Islam.

Papers which deal with the general problems of the Islamic guidance of social services will also be presented. For more information, contact:

IIIT - Cairo

26 Al-Jazirah al Wustah Street

Zamalek, Cairo, Egypt

Phone and Fax: 202-340-9520
IIIT - Riyadh

P.O. Box 25759

Riyadh 11471, Saudi Arabia

Phone: 966-1-491-5112

Fax: 966-1-491-0242 